\title{
VII. Account of a fatal accident which happened to a traveller on the glacier of Buet; with some cautions to those who through curiosity may visit the mountains of Swisserland, and particularly the glaciers
}

\section{M.A. Pictet}

To cite this article: M.A. Pictet (1800) VII. Account of a fatal accident which happened to a traveller on the glacier of Buet; with some cautions to those who through curiosity may visit the mountains of Swisserland, and particularly the glaciers, Philosophical Magazine Series 1 , 8:29, 53-61, DOI: $10.1080 / 14786440008562607$

To link to this article: http://dx.doi.org/10.1080/14786440008562607

曲 Published online: 18 May 2009.

Submit your article to this journal ¿

Џll Article views: 4

Q

View related articles $\asymp$ 


\section{$\left[\begin{array}{ll}53 & ]\end{array}\right.$}

VII. Account of a fatal Acctent wbicb bappened to a Trdveller on the Glacier of Buet; with fome Cautions to tbofe subo througb Curiofity may vifit the Mountains of Swifferland, and particularly tbe Glaciers. By M. A. PICTET, Prafeffor of Pbilofopby*.

A sentriment of curiofity, exceedingly natural, induces travellers from all parts of Europe to vifit Mont Blanc, the higheft point of the old world, and to examine the furrounding glaciers. Since the memorable afcenfion of the learned hiftorian of the Alps, thefe places have acquired a new degree of $\cdot$ intereft: the geologue, the mineralogitt, and the mere amateur repair thither with avidity; and even women are amply indemnified for the fatigue of the journey by the pleafure arifing from the view of objects entirely new to them, and by the amiable and friendly reception they meet with from the inhabitants. Every thing unites to make this excurfion, which is attended with no real dangers, the ufual object of all curious travellers who vifit Geneva and its environs.

The more this journey prefents attractions, the more it is of importance to make known the dangers to which travellers who undertake it may be expofed merely by imprudence or inattention. Our principal view is utility, and without doubt it is of utility to make known, in all places where this journal may circulate, dangers which are indeed great to thofe ignorant of them or who forgot them, but of little importance to thofe who are forewarned or cautioned to avoid them. Had we treated this fubject fome years ago, the fatal accident which lately took place, and to which we were almoft witneffes, would not, perhaps, have happened. This reflection will not allow us to hefitate any longer. The experience I have acquired by travelling among the mountains, either when accompanying my illuftrious friend Sauffure, or in ten journeys undertaken to the glaciers of Chamouni in particular, will perhaps entitle me to fome confidence from thofe whom I am defirous of faving from uneafinefs or 
danger: I thall, however, refer to the end of this article the cautions in this refpect which have been fuggefted to me by experience, and fhall proceed to an account of that event which induced me to take up my pen on the prefent fubject.

C. d'Eymar, præfect of Leman, an enlightened lover of the arts, and a paffionate admirer of the beauties of nature, having lately propófed to vifit the glaciers of Chamouni, a canton which at prefent forms the eaftern boundaries of the department under his adminiftration, invited me to accompany him ; and I readily embraced his obliging offer. We fet out on the 7 th of Augut, and fept the frit night at Sallenches, as travellers do in general.'

Next morning, during our firft hour's march, we met a young man on foot, accompanied by a peafant who was carrying a valife. We were ftruck with the melancholy and dejected air of this peafant. When we arrived at Servoz, three leagues from Sallenches, we learned from Deville, a very intelligent and experienced guide who attended us, that the morning of the day before, a ftranger, the companion of the young man we had met, being with his friend and a guide on the glacier of Buet, had fuddenly difappeared, at the diftance of fome paces before them, in a crevice of the glacier covered with fnow, which had given way under his feet. When they reached the mouth of the crevice, the bottom of which they could not perceive, the two furvivors called out a great number of times, but in vain, to their unfortunate companion fwallowed up in the abyfs; and they did not quit the place till they had lait all hope of his fafety. M. Zimpffen, the young man whom we met, when he arrived at Servoz, had given Deville a conmiffion in writing, to endeavour, if poffible, to difcover the body of M. Efchen, his friend, and to caufe it to be interred.

As fearcely twenty-four hours had elapfed fince the event, the fenfible mind of d'Eymar was ftruck with a ray of hope, and he immediately and officially enjnined Deville (for he hefitated, and not without reafon) to furnith himfelf with the neceffary means, to fet out in the utmoft hafte, accompanied by fuch a number of men as he prefumed might be neceffary, and to give him an account of whatever fhould be the refult. 
refult. It was at leaft a journey of nine hours from Servoz to the glacier in queftion; and as this glacier did not form any part of thofe we intended to vifit, it was impoffible for us to be informed of the iffue of the propofed fearch till we paffed Servoz on our return from Chamouni, to which we continued our route not without dejection.

It is with regret that $I$ am obliged to omit the details of the ftay we made in this interefting valley; they have a character which will always be imprinted in my remembrance, but they would be foreign to the prefent object. However, while the brave Deville and his companions are engaged with their enterprife, I hall venture to fufpend the impatience of my readers for a few moments in order to make them acquainted with the glacier of Buet, and the motives which might induce travellers to vifit it.

It is to Meffrs. De Luc, the two brothers, that philofophers and naturalifts are indebted for difcovering the poffibility of reaching this fummit covered with eternal fnow. It is an infulated mountain fituated in front of the central chain to which Mont Blanc and its glaciers belong, and feparated from them by a lower chain that runs in a parallel direction. This glacier may be feen from Geneva immediately on the left of the Môle. It appears under the form of a ridge not very falient, and which feems to be eafy of accefs. Meffrs. De Luc were, however, deccived in this refpeet, and the account of three attempts they made to reach it, the laft of which alone, on the 2oth of September 17.77 , was attended with fuccefs, is one of the moft interefting epifodes to be found in the works of any naturalift. It was a defire to dircover the law which the decreafe of heat in boiling watcr follows in proportion as it is raifed in the atmofphere, that induced them to vifit this mountain, and to brave, three different times, difficulties and dangers of various kinds to which they were expofed in attempting to reach a fummit that may be confidered as the utmoft poffible boundary of philofophical obfervation. Honour to that fcience which infpires courage fo perfevering, and which produces it in fucceeding generations! Our daring countrymen never furpected that, feventeen years after this expedition, Sauffure would 
would repeat their experiment on Mont Blanc itfelf, that is to fay, about $85^{\circ}$ toifes higher than they were able to afcend after great danger and fatigue.

Some years ago, a much eafier route for arriving at the furmmit of Buet or La Mortine (for it is known by that name alfo) than that followed by Mefrrs. De Luc was difcovered, and by this route $I$ afcended it twice without experiencing any difficulty. You firft neep at Chalets de Villy, the laft place of pafture of the valley which begins at Servoz and terminates at the glacier of Buet. From Vilty you proceed to the Col de Salenton by a path practicable for mules; you then encounter the mountain on its eaftern and fouthern fides, and, paffing alternate declivities of fnow and flate, reach the fummit at the end of two hours and a half. The mean of two obfervations of the barometer which I made there, and which were very little different in their refults, gave me 1594 toifes for its height above the level'of the fea.

The mountain itfelf prefents nothing very interefting in $\mathbf{2}$ lithologic point of view; it conffits of late intermixed with veins of rotten quartz, or quartz fimilar to ftalactites; but as a belvidere, nothing in my opinion exifts that can be compared to it. You here embrace at one view the whole fpace comprehended between Jura on the weft, as far as the mouths of the Rhone on the eaft, and, on account of this circumftance alone, I confidered this mountain as exceedingly proper for receiving fignals in an intended meafurement of a degree of latitude and two degrees of longitude in the parallel of Geneva ; a,plan which may be found detailed in a memoir publithed in the Philofophical Tranfactions of the Royal Society of London for the year I79I*.

* I cannot convey a better idea of the fituation of this fpot than by quoting the words of M. De Luc:- "It is difficult to give a defcription in words when they do not awaken fenfations which have been felt; I do not, therefore, flatter myfelf with the hope of exciting in the minds of my readers thofe which $I$ then experienced. The moft profound filence prevailed in thefe regions; we perceived that they were not made for living beings; they were as little known to our guides as to us. The Chamois goats never approach them, and confequently no hunter had ever afcended fo far. 


\section{In my fecond joumey to mount Buet, 1 was under the difagreeable necefity of being conltantly enveloped by \\ clouds}

" This fenfation of profound folitude was one of thofe which we could molt eafily explain, but it does not explain our fituation. We were on an inmenfe extent of how, the whirenefs of which nothing altered. The rays of the fun, rolleded in a fraight line from the fnow towards that luminary, fhowed us how fmooth it was; and this fmoothnefs the irragination exterded to every thing alouad. We fav nothing but this fnow, and tile heavens, towards which it was terminated ia sarious folds, delicatcly rounded like thofe beautiful argenrine clouds which are fometimes feen flyating majeftically in the pure atmolphere. This was exactly what produced the excrardinary feufarion which we then experienced. We actuaify thrught ourlelves fufpended in the air on one of thefe clomos - And what kind of air? Never had we bufore feen ir of fuch a crilour. It was blue, daik and bright at the lame time, which produced.an inexpreftible fenlation of imm:nity.

"It was near noon when we arrived; and, on raifing our heads above the veil which fo long conceated from us the eaftern part of the horizon, we fuddenly difcovered the immenfe chain of the Alps in an extent of more than fifty leagues. On whatever lide we turned our eyes, the whole horizon was covered with pountains. Las boundary on the weft was nothing but the thicknefs of the air; for we overlooked the chain of Jura, diftant abour thirteen or fourteen lcagues, fo much that we could have feen the plans of Franche-Comté and Buigundy, if the air had been fufficiently tran $f_{p}+$ rent. On the fouth-weft our view extended as far as Misunt Cenis, and on the north-enst probably as far as Saint Gothard. We were far prifed above all the defles of the Alps, and only a few of their peaks were clevated above us.

" It all this vaft fpace, where mountains were accumulared on each nther, we could difcover no plain but in a finall corner to the weft, the middle of whicis was uccupied by Geneva; and on the north-eaft we faw, almolt from one end to the other, the large vallcy througtr which the Ithone flows, from the place whure it fal's from the mountains, as far as Sirt, the capical of the Valais, dittent from the place where we were nine or ten leagues. All the reft was filled with mountains.

"The details as well as the ensemble wou'd have excited the attention of the molt indifterent betolder. A fingle view of the immenfe quantity of ice and inow whtch covers the $A / p$ s will be fufficient to fatisfy the fpedator refpe Eung the duration of the Khone, the Rhine, the Po, and the Danube. It infpires us with an idca that this is their common refervoir, and that it is fuffcient ro fupply them with water during feveral years of drought. We compared, without having necd of calculation, cheir ftreams with their fources. Thefe tources appeared to us only (mall)

VoL, VIII. 
clouds dyring the fix hours I remained on it. I was exceedingly cold, and, in order to warm ourfelves, I and my guides were obliged to confruct a hut on the ridge of rocks neareft the fummit. We had at hand large pieces of flate, and our building was to folid that it ftill exifts, and has theltered more than one curious traveller from the feverity of the weather:

The glacier, which covers this fummit, differs from the greater part of thofe accumulations of ice known under that name in this refpect, that the latter generally occupy the valleys, or the defiles in which the ice has not been originally formed, but to which it has funk down by its own weight, and the preffure of the ice above it; wheres the ice of Buet has been formed in the place where it exifts; and at that height in our parallel the fnow never melts in fummer. This mountain, therefore, may ferve to determine with fome precifion the loweft boundary of the fnow in our climates.

Thus, for example, by obferving from Geneva, through a telefcope furnithed with a micrometer, the vertical angle comprehended between the fummit of the glacier and the loweft boundary of the fnow, I found it to be $16^{\prime \prime}{ }_{14}{ }^{\prime \prime}$, which, taking the diftance of Buet from Geneva at 29820 toifes, correfponds to $14 \mathrm{I}$ toifes, the diftance of this boundary below the fummit, which places it at 1453 tojfes above the level of the fea.

It may here be afked, what is the mean annual temperature at this beight in our latitude? We have pointed out fomewhere in our Journal a very fimple formula, which Sauffure deduced from a great number of obfervations, and which reprefents very well the law of the decrement of the mean heat of the atmofphere from the bottom upwards. This decrement is a hundredth part of a degree of the thermometer of Reaumur per toife of perpendicular elevation. This for-

rills, when compared with the valleys filled with ice, from which they flowed. Mont Blanc, which rofe above thefe valleys, feemed capable of furnithing alone, for a long time, a fufficiency of water for a river, fo much was it loaded with ice from the top to the bottom; that is to fay throughout a prodigious extent. - Recberches fur les Modifications de l'Aimojpbere, vol. ii. p. 390 : 
inula, therefore, applied to the mean temperature at the level of the fea, in the parallel of $46^{\circ}$ (the latitude of Buet), as eftablithed in Dr. Kirwan's Work on the Temperature of the Globe, viz. $5^{6} 4^{\circ}$ of Falirenheit, or $10^{\circ}, 8$ of Reaumur, will give for 1453 toifes 14.53 degrees to be deducted; which makes the mean annual temperature of the lower boundary of the fnow, in that parallei, to be 3.63 degrees below zero.

It is not furprifing, therefore, that this mountain fhould be crowned with a glacier, fince the fnow which falls there during the cold feafon, never entirely melts in the fummer. The water produced by the partial melting of the furface of the fnow filters through the prorous fnow beneath it, and freezing in its interftices gradually converts it into ice. In this manner-is formed an accumulation, the thicknefs of which M. De Luc endeavoured to eftimate from the following obfervation :

"We judged," faid he, "by the pofition of thefe fmall rocks, about 200 feet lower than the higheft part of the ice, that they formed a part of the real fummit of the mountain. The whole mafs above them was nothing but ice, in the form of a cone, cut through its axis, 200 feet in height, with a very extenfive bafe, and refting on the im-

* I had occafion not long ago to difcufs this formula with a philofopher, who obfersed to me, that, according to its nature, it was inpolfible it could be cotred; becaufe the denfity of the air, an element on which the prefervation of heat in the different ftrata of the atinofphere effentially depends, decreafes in geometrical progreffion; while the heights in toifes, which reprefent the temperatures, proceed in arithmetical progieffion. I admitted the juftncfs of the obfervation, fpeaking mathematically; but, in a phyfical point of view, as the formula is compofed of co-efficients, fome of them unknown or inappreciable, which gives to the temperature an arithmetical progreffion, decreafing from the botrom upwards, it is no lefs true, that this formula, however deceptive it may be, reprefents the mean refults of obfervations fufficiently well to be employed with convenience, when an approximative quantity only is neceffary: and this was exadly the cafe. The quetion was the mean temperature of mount Saint Bernard, the philofopher was Bonaparte, and the difcuffion took place at table, and even in the apartment of the celebrated man whofe theory and calculations I was ondeapouring to defend. 
mente extent of petmanent ice, which covers the whole de* clivily of the fammit."

But I learned, not without furplife mixed with horror, by the event, of which I am going to give au account, that this glacier, fo often rifited by travellers, and which I twice traverfed myfelf witia perfect fecurity, contains fome of thofe fiffures, covered whith funw, which renders others dangerous when the proper precautions are not cmployed.

During our ftay at Chamouni, C. d'Eymar having heard that the guide, who accompanied the unfortunate Edclien, refided fomewhere in the valley, fent for him, to learn the particulars of the accident. When be arrived, defpair was ftith painted in his looks and whole countenance; but we leamed nothing from him that we dial not before know. He was a guide, fetceted by chance, who fermed to be little acquainted with the monntains, and who, however, as he told us, had requefted $\mathrm{N}$. Efchen, when they arrived at the glacier, not to feparate from this two companions. Hurried on, however, by that undefrribable fenfation which people fometianes experience when they reach high fummits, and obferving at the top of the glacier, a little diftance before him, two chamoy bunters, who were refting themfelves, he hurried forwarts to join them; and it was then that he difappeared.

We thall noiv return to enr narrative. As we pafed Servoz on the morning of the third day, the body of the unfortunate Efchen was conveycd thither. We viewed it with the livelieft emotion; and by minute infpection we were convinced that he har not furviced his fall a fingle moment. $1 \mathrm{I}^{\top} \mathrm{e}$ were fully confrimed in this opinion by the details which were given to us, and by obferving that three of the real ribs on each fide were broken, and that there was a great depreffion of the fternum; fymptoms which indicate that the unfortunate young man had experienced the moft fudden and molt violent compreffion. The body was no ways disfigured, and his features, in perfect harmony, excited no idea of his having fuffered pain. We learned by the pafiport found in his pockets, along with other articles, that his name was Frederick Augultus Efchen; that he was born 
in the bithopric of Lubec, and that he was twenty-three years of age.

[To be concluded in the next Number.]

VII. Memoir on tbe Ibis of the Antient Egyptians. By C. Cuvier*.

HVERY one has heard of the Ibis, a bird to which the antient Egyptians paid divine honours; images of which they placed in their temples; which they fuffered to wander about unmolefted in their cities; which they embalmed with as much care as they did their relations; to which they afcribed virginal purity, and an inviolable attachment to a country of which it was the emblem, and the figure of which the gods would have affumed, had they been forced to adopt one mortal.

No animal ought to have been fo eafy to be diftinguined, for there is none of which they have left fo many excellent defcriptions, correct coloured figures, and even the birds themfelves carefully preferved with their feathers, under the triple covering of that ftrong preferver bitumen, thick and clofe bandages, and of frong vafes well covered with maftic. Yet among all the modern authors who have fpoken of the ibis, there is none but Bruce, a traveller celebrated by his courage and his knowledge of natural hiftory, who has avoided error in regard to the real fpecies of this bird; and yet his ideas, however correct, have not been adopted by naturalifts.

After feveral changes of opinion refpecting the ibis, naturalifts at prefent feem to agree in giving this appellation to a bird, a native of Africa, nearly of the fize of the ftork, with white plumage, and the wing feathers black; raifed on long red legs, and armed with a long bent bill, fharp at the edges, indented at the extremity, round at its bafe, and of a pale yellow colour, and having its face covered with a yellow fkin, deftitute of feathers, and not extending beyond the eyes.

* Formsal de Fby/sque, Fructidor, an. 8. 